\title{
Consequences of eight consecutive applications of equine chorionic gonadotropin on ovarian follicle development and ovulation in bos indicus cows
}

\author{
Consequências do uso consecutivo de oito doses de gonadotrofina coriônica \\ equina no desenvolvimento folicular e ovulação de vacas bos indicus
}

\author{
Bhárbara Delboni Stuhr ${ }^{I}$ Isaac Santos Gil ${ }^{I}$ Tracy Ferreira Lacerda \\ Mauricio Gomes Favoreto ${ }^{I}$ Bárbara Loureiro ${ }^{{ }^{*}}$
}

\section{ABSTRACT}

The equine chorionic gonadotropin (eCG) is a glycoprotein produced in mare endometrial calices. In bovine, it is used in estrus synchronization protocols. However, studies have shown that it is potentially immunogenic and its effect can decrease after repetitive use. This study aimed to evaluate antral follicle dynamics, corpus luteum (CL) and ovulation rate in bos indicus cows submitted to an estrus synchronization protocol in association with eCG for eight times consecutively. Ten cyclical, multiparous, and pasture raised beef cows were divided into two groups: control group $(n=5)$ and eCG group $(n=5)$. In 30 day interval, all animals were synchronized with the same estrogen/ progesterone based protocol, totalizing 8 re-synchronizations. Cows in the treatment group received $300 I U$ eCG 48 hours prior to the presumable ovulation. Ultrassound examinations were performed on Day 4 of the protocol (approximately 1.5 days after follicle recruitment) to count antral follicles, on Day 10, to count antral follicles and to measure size of the largest follicle and on Day 18 to measure the diameter of the CL. No difference $(P>0.05)$ between follicular growth and size of the pre-ovulatory follicle was reported between groups. Cows treated with eCG had a larger $(P<0.05) C L$ and increased $(P<0.05)$ ovulation rate $(18 \mathrm{~mm}$ and $92 \%$, respectively) when compared with control group (14.1 $\mathrm{mm}$ and $80 \%$, respectively). Furthermore, consecutive treatments did not affect $C L$ nor ovulation rates. In conclusion, eCG treatment increased CL size and ovulation rate even after 8 consecutive treatments.

Key words: corpus luteum, eCG, fertility, immunity, FTAI.

RESUMO

A gonadotrofina coriónica equina (ECG) é uma glicoproteína produzida nos cálices endometriais da égua. Em bovinos, é utilizada em protocolos de sincronização do estro. Estudos têm mostrado que ela é potencialmente imunogênica $e$ seu efeito pode diminuir depois de utilização repetida. $O$ objetivo do presente trabalho foi avaliar a dinâmica folicular, o diâmetro do corpo lúteo (CL) e taxa de ovulação em vacas bos indicus submetidas a um protocolo de sincronização estral com eCG por oito vezes. Dez vacas de corte, ciclicas, multiparas e solteiras foram divididas em dois grupos: grupo controle $(n=5) e$ grupo eCG $(n=5)$. Em um intervalo de 30 dias, os animais foram sincronizados com um protocolo de estrógeno/progesterona, totalizando 8 re-sincronizações. Os animais do grupo tratamento receberam 300UI eCG 48 horas antes da provável ovulação. Exames ultrasonográficos foram realizados no dia 4 do protocolo (aproximadamente 1,5 dias após o recrutamento folícular), para contar folículos antrais, no dia 10, contar folículos antrais e medir o tamanho do maior folículo e, no dia 18, para medir o diâmetro do CL. Não foi encontrada diferença $(P>0,05)$ entre folículos no dia 4 ou 10. Vacas tratadas com eCG tinham um maior $(P<0.05) C L$ e elevada $(P<0.05)$ taxa de ovulação $(18 \mathrm{~mm}$ e $92 \%$, respectivamente) quando comparadas ao grupo controle $(14,1 \mathrm{~mm}$ e $80 \%$, respectivamente). Além disso, tratamentos consecutivos não afetaram o CL nem as taxas de ovulação. Em conclusão, o tratamento com eCG aumentou o tamanho do CL e taxa de ovulação, mesmo depois de 8 tratamentos consecutivos.

Palavras-chave: corpo lúteo, fertilidade, imunidade, IATF.

\section{INTRODUCTION}

Equine chorionic gonadotropin (eCG) is a glycoprotein hormone molecule (ROY et al., 1999) produced in the endometrial calices of pregnant mares between 40 to 130 days of gestation (CATCHPOLE \& LYONS, 1934). When applied exogenously, the eCG creates conditions for follicular growth and ovulation by binding FSH and LH follicle receptors and LH receptors of the corpus luteum (BARUSELLI et al., 2004).

\footnotetext{
ILaboratório de Fisiologia da Reprodução, Universidade Vila Velha (UVV), Av. Comissário José Dantas de Melo, 21, 29102-020, Vila Velha, ES, Brasil. E-mail: barbara.loureiro@uvv.br. "Corresponding author. 
Association of eCG with hormonal estrus synchronization protocols can increase ovulation and pregnancy rates, especially in post-partum and low body condition score (BCS) cows. In these animals, eCG induces ovulation of the largest and most functional follicle, which therefore will develop a better corpus luteum (CL), increasing progesterone, which favors embryonic development and survival (RENSIS \& LÓPEZ-GATIUS, 2014).

The eCG should also be used in lactating females, as it eliminates temporary calf removal, which when held for only 48 hours, causes stress on the mother and calf (SILVEIRA et al., 2010). Conversely, eCG was not beneficial when used in Holstein and post-partum Nellore cows that were in a good BCS (ERENO et al., 2007; PULLEY et al., 2013)

However, due to a heterologous origin, a high molecular weight, high degree of glycosylation and longer half-life, eCG becomes a potentially immunogenic molecule when injected in cattle (DRION et al., 2001). Thus, animals that undergo successive treatments with eCG appear to become refractory to this molecule, not effectively responding to the treatment (DRION et al., 2001).

The production of anti-eCG antibodies has been reported in goats, sheep, cows, and rabbits (ROY et al., 1999a; ROY et al., 1999b; DRION et al., 2001; THEAU-CLEMENT et al., 2008, respectively). These antibodies are responsible for reducing the interaction of eCG with $\mathrm{FSH}$ and $\mathrm{LH}$ receptors (MAUREL et al., 2003). As a consequence a delay could occur in the LH surge and ovulation, reducing the females' fertility. Some studies report antibody production from the first eCG application while others claim that there is an additive effect in repeated applications (ROY et al., 1999a; DRION et al., 2001; MANTOVANI, 2010).

Thus, this study aimed to evaluate follicular growth, diameter of the pre-ovulatory follicle and $\mathrm{CL}$, as well as ovulation rate in bos indicus cows submitted to an estrous synchronization protocol associated with eCG for eight consecutive times.

\section{MATERIALS AND METHODS}

The experiment was performed from January to September 2015 at a farm located in Linhares, ES (19 $11^{\prime} 4^{\prime \prime} \mathrm{S}$ and $\left.39^{\circ} 49^{\prime} 35^{\prime \prime} \mathrm{W}\right)$. Ten crossbred bos indicus cows, aged between 4 and 6 years old, with BCS ranging from 3 and 3.5 (scale of 1-5; LOWMAN et al., 1976), multiparous and non suckled, were used. The animals were pasture raised (Brachiaria humidicola), receiving mineral salt and water ad libitum. All ten animals were from the same commercial farm and had been submitted to two estrus synchronization protocols with eCG (200 IU; Novormon; Zoetis, São Paulo, SP, Brazil) in the previous three reproductive breeding seasons. All the cows became pregnant in each season and had the same parity number.

The animals were divided into two groups: control $(n=5)$ and eCG $(n=5)$. The entire hormonal treatment was done in all the animals in each protocol, being repeated 8 times with a 30 day interval. The hormonal protocol and ultrasound scheme are shown in figure 1.

Briefly, all females received, on a random day of the estrous cycle, $2 \mathrm{mg}$ of estradiol benzoate intramuscularly (Sincrodiol, Ouro Fino, São Paulo, SP, Brazil) and an intravaginal progesterone implant (PRIMER; 1g of progesterone; Tecnopec, Guaçu, SP, Brazil), being considered as Day 0 (Day 0).

On Day 4 of the hormonal treatment (approximately 1.5 days of follicular recruitment; SÁ-FILHO et al., 2011) animals were evaluated by ultrasound (US; MINDRAY, DP-2200VET model with $7.5 \mathrm{MHz}$ linear transducer) for antral follicle count and presence and location of preexisting corpus luteum (CL) prior to hormonal treatment.

On Day 7, 500mg of sodium cloprostenol (Ciosin; MSD Saúde Animal, Cotia, SP, Brazil) was

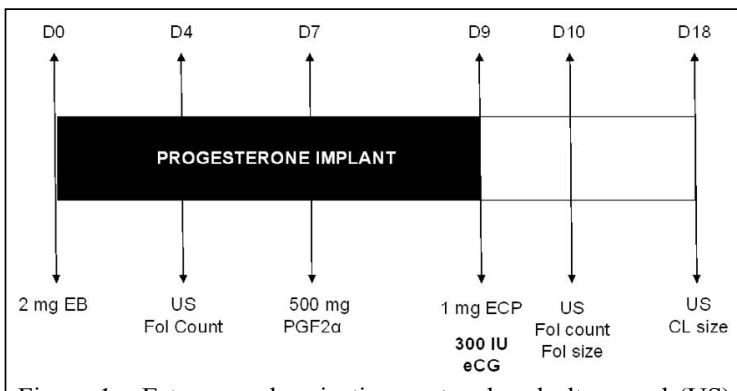

Figure 1 - Estrus synchronization protocol and ultrasound (US) scheme performed in bos indicus cows from control (without eCG) and treatment (eCG) groups. On Day 0 (D0; an aleatory day of estrus cycle) cows received $2 \mathrm{mg}$ of estradiol benzoate and a progesterone vaginal implant was inserted, on D4 of the protocol (approximately 1.5 days after follicle recruitment) antral follicles (fol) were counted and on D7 cows received and injection of PGF2 $\alpha$. On D9 the implant was removed and cows received $1 \mathrm{mg}$ of estradiol cypionate, cows from the treatment group also received 300IU of eCG. On D10 an ultrasound examination was performed to count the number of follicles and measure the diameter of the largest follicle. On D18 another ultrasound examination confirmed the presence and measured the diameter of the corpus luteum (CL). 
administered intramuscularly. After 48 hours, on Day 9 , the intravaginal implant was removed and $1 \mathrm{mg}$ of estradiol cypionate applied intramuscularly (ECP; Zoetis, São Paulo, SP, Brazil). Females belonging to the eCG group also received in this time period 300 IU of ECG intramuscularly (Novormon; Zoetis, São Paulo, SP, Brazil). All handling was performed at the same time (0800).

On Day 10 the amount of antral follicles and diameter size of the largest follicle in the right and left ovary was evaluated using an US. On Day 18 (seven days after presumable ovulation) an ultrasound evaluation for presence and diameter of the corpus luteum in response to the hormonal treatment was performed.

Statistical analysis

The effect of treatment (control or eCG), protocol number and its interaction on the number of follicles on Day 4 and Day 10, follicle size at Day 10 and CL size on Day 18 in the right or left ovaries was analyzed by analysis of variance using the PROC MIXED procedure of SAS (SAS for Windows, Version 9.0, Cary, NC), with the animal (cow) being considered the subject and protocol number the repeated measure. Individual comparisons were performed using the PDIFF function (probability of individual differences). Percentage of animals ovulating per protocol was assessed by analysis of variance using the PROC GLM procedure of SAS; data were transformed to arcsine before analysis. Results are presented as least square means (LSmeans) and standard error of the mean (SEM).

\section{RESULTS}

Number of follicles on Day 4 and Day 10, follicle size on Day 10 and CL size on Day 18 as well as ovulation rate per treatment (control or eCG) per protocol number (1 to 8 ) are presented in table 1 .

No difference was observed in the number of antral follicles on Day 4 between control and eCG treated animals nor an interaction between protocol number and treatments $(\mathrm{P}>0.05$; Figure $2 \mathrm{~A})$. Also, no difference was observed in the number of follicles ( $\mathrm{P}>0.05$; Figure 2B) or size of the largest follicle on Day 10 (Figure 2C) between control or eCG treated animals nor an interaction between protocol number and treatment $(\mathrm{P}>0.05)$.

Cows treated with eCG had a larger $(\mathrm{P}=0.04) \mathrm{CL}$ on Day 18 when compared with cows from the control group (Figure 2D). Furthermore, ovulation rate was higher $(\mathrm{P}=0.03)$ on eCG treated cows when compared with control cows $(92 \pm 0.3$ vs. $80 \pm 0.3$ ). Aditionally, the administration of eight doses of eCG consecutively did not alter ovulation rate per protocol $(\mathrm{P}>0.05)$.

\section{DISCUSSION}

The use of CG for eight times consecutively did not decrease ovulation as hypothesized previously or influence the follicular wave of the subsequent estrus cycle. Furthermore, animals in the eCG group had a larger CL, but no difference was observed in the number of follicles or the pre-ovulatory follicle size after eCG administration.

The eCG is usually used in estrus synchronization protocols as a follicle developing agent due to its FSH- and LH-like activity (TORTORELLA et al., 2013). However, some authors have suggested that due to the protein's size and long plasma half-life an immune response against the eCG molecule can be developed by the animals which would decrease the

Table 1 - Number of follicles (Num Fol) on Day 4 (D4) and Day 10 (D10), follicle size on day 10 (D10), corpus luteum (CL) size on day 18 (D18) and ovulation rate of bos indicus cows submitted to an estrus synchronization protocol without (control) or with $300 \mathrm{IU}$ of equine chorionic gonadotrophin (eCG). Results are LS means \pm standard error.

\begin{tabular}{|c|c|c|c|c|c|c|c|c|c|c|}
\hline \multirow{2}{*}{$\begin{array}{l}\text { Protocol } \\
\text { Sequence }\end{array}$} & \multicolumn{2}{|c|}{-------Fol D4 (n)------- } & \multicolumn{2}{|c|}{-------Fol D10 (n)------- } & \multicolumn{6}{|c|}{---Fol size D10 (mm)--- ----CL size D18 (mm)---- ---Ovulation rate $(\%)--$} \\
\hline & Control & $\mathrm{eCG}$ & Control & $\mathrm{eCG}$ & Control & $\mathrm{eCG}$ & Control & $\mathrm{eCG}$ & Control & $\mathrm{eCG}$ \\
\hline $1^{\text {st }}$ & $20 \pm 2.85$ & $21.6 \pm 2.85$ & $22.4 \pm 3.5$ & $20.6 \pm 3.5$ & $10.728 \pm 1.7$ & $11.312 \pm 1.7$ & $18.52 \pm 3.3$ & $17.66 \pm 3.3$ & 80 & 80 \\
\hline $2^{\text {nd }}$ & $16.8 \pm 2.85$ & $19.4 \pm 2.85$ & $24.2 \pm 3.5$ & $18.6 \pm 3.5$ & $9.19 \pm 1.7$ & $12.14 \pm 1.7$ & $12.64 \pm 3.3$ & $17.94 \pm 3.3$ & 80 & 100 \\
\hline $3^{\text {rd }}$ & $18.6 \pm 2.85$ & $16.8 \pm 2.85$ & $20.2 \pm 3.5$ & $16.4 \pm 3.5$ & $9.32 \pm 1.7$ & $11.33 \pm 1.7$ & $12.78 \pm 3.3$ & $15.1 \pm 3.3$ & 80 & 80 \\
\hline $4^{\text {th }}$ & $19.4 \pm 2.85$ & $17.2 \pm 2.85$ & $20.4 \pm 3.5$ & $22.2 \pm 3.5$ & $9.91 \pm 1.7$ & $8.85 \pm 1.7$ & $14.26 \pm 3.3$ & $12.14 \pm 3.3$ & 80 & 80 \\
\hline $5^{\text {th }}$ & $16.6 \pm 2.85$ & $12.8 \pm 2.85$ & $16.6 \pm 3.5$ & $13.4 \pm 3.5$ & $9.27 \pm 1.7$ & $10.76 \pm 1.7$ & $13.22 \pm 3.3$ & $22.78 \pm 3.3$ & 80 & 100 \\
\hline $6^{\text {th }}$ & $23.4 \pm 2.85$ & $13.4 \pm 2.85$ & $16 \pm 3.5$ & $12.4 \pm 3.5$ & $11.56 \pm 1.7$ & $9.54 \pm 1.7$ & $10.28 \pm 3.3$ & $19.26 \pm 3.3$ & 60 & 100 \\
\hline $7^{\text {th }}$ & $17.8 \pm 2.85$ & $15.4 \pm 2.85$ & $23 \pm 3.5$ & $16.6 \pm 3.5$ & $10.44 \pm 1.7$ & $11.04 \pm 1.7$ & $16.58 \pm 3.3$ & $18.36 \pm 3.3$ & 100 & 100 \\
\hline $8^{\text {th }}$ & $17.8 \pm 2.85$ & $13.4 \pm 2.85$ & $14.8 \pm 3.5$ & $20 \pm 3.5$ & $8.50 \pm 1.7$ & $11.19 \pm 1.7$ & $14.98 \pm 3.3$ & $21.4 \pm 3.3$ & 100 & 100 \\
\hline
\end{tabular}



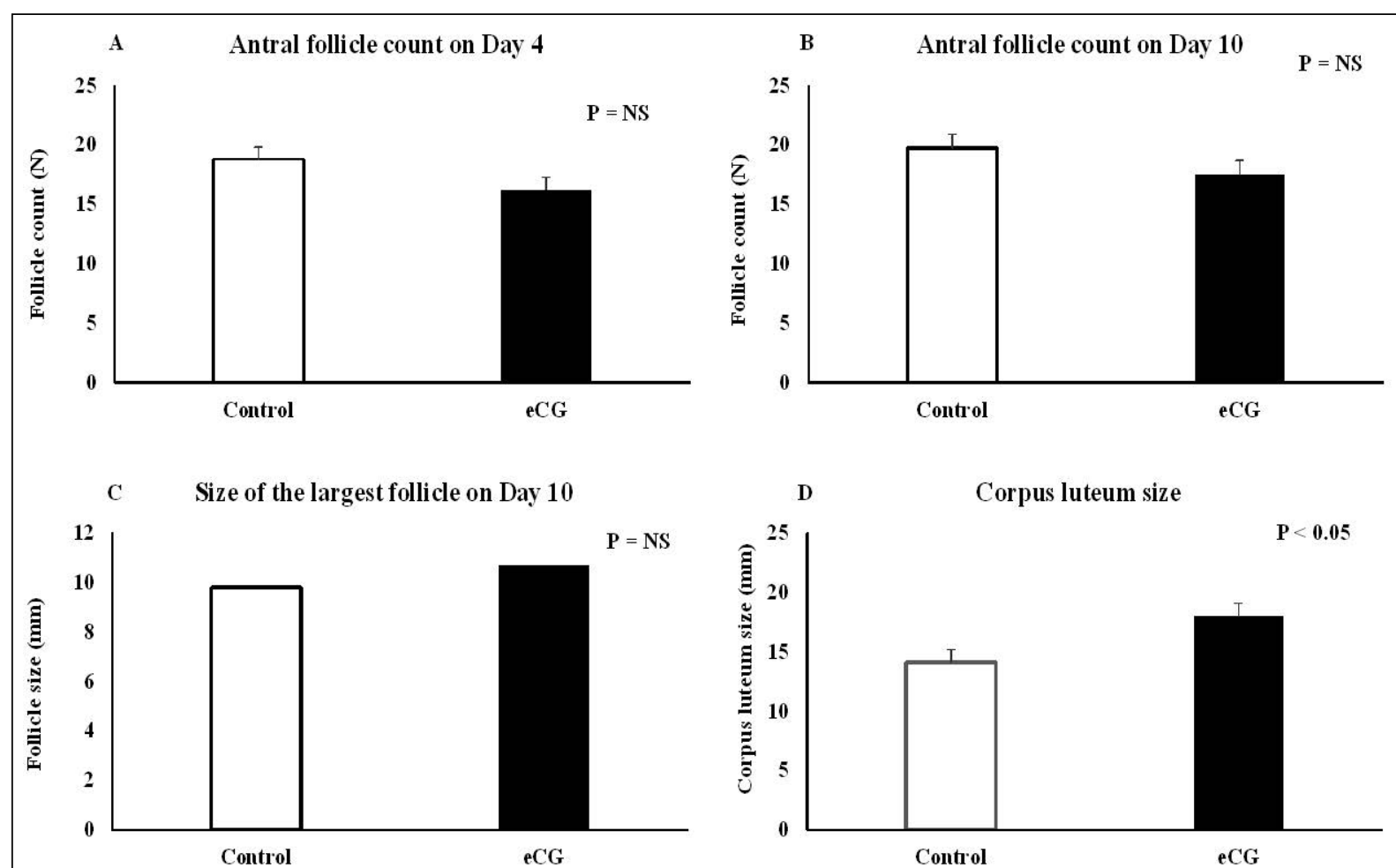

Figure 2 - Ultrasound results from control and eCG treated cows synchronized with an estrogen-progesterone based protocol. Panel A - Antral follicle count on Day 4 (approximately 1.5 days after follicle recruitment). Panel B and C - Antral follicle count and size of the largest follicle on Day 10 (approximately 7 days after follicle recruitment). Panel D - Corpus luteum diameter (mm) measured on Day 18 (approximately 7 days after the presumable ovulation). Differences were considered statistically significant when $\mathrm{P}<0.05$.

eCG's effect after repetitive use (revised by DRION et al., 1998; ROY et al., 1999a; DRION et al., 2001).

The positive effect of eCG on follicle development has not been completely determined. Some authors have shown that it can increase preovulatory follicle size and that would end up in a larger CL (TORTERELLA et al., 2013). The size of the CL is important for progesterone secretion and pregnancy maintenance (RIGOGLIO et al., 2013; MARTINEZ et al., 2014). However, in previous studies eCG did not influence pre-ovulatory follicle size however it rather enhanced CL size (BARUSELLI et al., 2004; PULLEY et al., 2013; MARQUEZINI et al., 2014). Even though it was not observed an increase in preovulatory follicle size it was observed a larger CL. An increase in progesterone concentration has also been described as a positive effect of the eCG (SANTOS et al., 2001; BARUSELLI et al., 2004; MARQUEZINI et al., 2014). The eCG acts increasing the number of lutheal cells and mitochondrias that in turn increases pregnenolone synthesis (RIGOGLIO et al., 2013).

The use of eCG is more beneficial when animals are post-partum, lactating or in a low BCS (SILVEIRA et al., 2010; RENSIS \& LÓPEZ-GATIUS,
2014). In this study single non-lactating cows with good BCS were used to test the negative effect of repetitive use of eCG. The above categories (post-partum, lactating or in a low BCS) were avoided so no other factor would negatively influence antral follicle development, ovulation rate and CL formation. We believed that in any of these situations the result (no detrimental effect of consecutive eCG use) would be the same.

The eCG administration can increase the concentration of anti-eCG antibodies after the first use (ROY et al., 1999b; MANTOVANI, 2010) and some studies have reported an additive effect of subsequent treatments (ROY et al., 1999a; DRION et al., 2001). Furthermore, most studies have concluded that there is an animal individuality to the immune response against eCG (DRION et al., 2001; MANTOVANI, 2010). This immune response can be especially deleterious to fertility. The anti-eCG antibodies can delay the LH surge and in consequence ovulation will be lated desynchronizing with the moment of FTAI (ROY et al., 1999a; MAUREL et al., 2003). Furthermore, female goats with high antieCG concentration showed low fertility after FTAI due to a low follicle development and decreased

Ciência Rural, v.46, n.11, nov, 2016. 
steroid genesis (ROY et al., 1999a). MANTOVANI (2010) observed a negative correlation between the concentration of anti-eCG antibodies and number of antral follicles $(>6 \mathrm{~mm})$ after the second treatment with 2000IU eCG. However, when a high dose of eCG (800IU) was administered before follicle deviation it increase double ovulation rate (MARTINEZ et al., 2014).

However, most of the studies that show an immunogenic action of eCG were performed using high doses of the hormone (500 IU in goats and sheep and 2000 IU in cows; ROY et al., 1999a; ROY et al., 1999b; DRION et al., 2001, respectively). Here, it was used $300 \mathrm{IU}$, dose that is routinely used in fixed time artificial insemination (FTAI) programs in bos indicus cows. Treatments were repeated eight times in a 30 day interval. Usually, a bos indicus cow will be hormonally stimulated one or two times per breeding season and will have approximately eight months of interval within seasons. It has been shown that a longer interval within injections will decrease eCG immunogenicity and increase immunity response time (ROY et al., 1999).

Here we showed that even after the eighth treatment the cows in the eCG group continued to ovulate. Furthermore, cows in the eCG group had a larger CL which is associated with better pregnancy rates and lower pregnancy losses (NOGUEIRA et al., 2012; GONELLA-DIAZA et al., 2013). It is believed that these results can be extrapolated to the field and in the dose of 300IU eCG can be repeatedly used in subsequent breeding seasons without any deleterious effect on fertility.

\section{CONCLUSION}

The repeated use of eCG, in the conditions of the present study, did not decrease antral follicle growth or ovulation rate. Contrariwise, the use of eCG in the FTAI protocol increased CL size.

\section{BIOETHICS AND BIOSSECURITY COMMITTE APPROVAL}

The experiment was approved and followed the guidelines of the Ethics Committee for Animal Use of the Universidade de Vila Velha and the Sociedade Brasileira de Ciência em Animais de Laboratório (CONCEA), under the registration number 349/2015.

\section{ACKNOLEDGEMENTS}

We thank Fundação de Amparo à Pesquisa e Inovação do Espírito Santo (FAPES) for the scholarships of Bharbara Stuhr, Isaac Gil and Tracy Lacerda.

\section{REFERENCES}

BARUSELLI, P.S. et al. The use of hormonal treatments to improve reproductive performance of anestrous beef cattle in tropical climates. Animal Reproduction Science, v.82-83, p.479-486, 2004. Available from: <http://dx.doi.org/10.1016/j.anireprosci.2004.04.025>. Acessed: Dec. 2015. doi: 10.1016/j.anireprosci.2004.04.025.

CATCHPOLE, H.R.; LYONS, W.R. The gonad stimulating hormone of pregnant mares. American Journal of Anatomy, v.55, p.167-227, 1934. Available from: <http://dx.doi.org/10.1002/aja.1000550202>. Acessed: Dec. 2015. doi: 10.1002/aja.1000550202.

DRION, P.V. et al. Increase of plasma eCG binding rate after administration of repeated high dose of eCG to cows. Reproduction Nutrition Development, v.41, p.207-215, 2001. Available from: <http://dx.doi.org/10.1051/rnd:2001124>. Acessed: Dec. 2015. doi: 10.1051/rnd:2001124.

ERENO, R.L. et al. Pregnancy rates in milking Nelore cows submitted to progesterone treatment associated to temporary calf removal or eCG administration. Revista Brasileira Zootecnia, v.36, n.5, p.1288-1294, 2007. Available from: <http://dx.doi. org/10.1590/S1516-35982007000600010>. Acessed: Dec. 2015. doi: $10.1590 / \mathrm{S} 1516-35982007000600010$.

GONELLA-DIAZA, A.M. et al. Corpus luteum diameter and embryo developmental stage are associated with pregnancy rate: data analysis from 17,521 embryo transfers from a commercial in vitro bovine embryo production program. Animal Reproduction, v.10, n.2, p.106-111, 2013. Available from: <http://www.cbra.org. br/pages/publicacoes/animalreproduction/issues/download/v10n2/ pag106-111\%20(AR489).pdf>. Acessed: Dec. 2015.

LOWMAN, B.G. et al. Condition scoring of cattle. Bulletin East Scotland College Agriculture, v.6, p.8, 1976.

MARTINEZ, M.F. et al. Development of a GnRH-PGF2 $\alpha$ progesterone-based synchronization protocol with eCG for inducing single and double ovulations in beef cattle. Journal of Animal Science, v.92, p.4935-4948, 2014. Available from: $<$ http://dx.doi.org/10.2527/jas2013-7512>. Acessed: Dec. 2015. doi: $10.2527 /$ jas2013-7512.

MANTOVANI, A.P. Resposta Imunológica contra gonadotrofina coriônia equina (eCG) em novilhas Bos taurus e Bos indicus. 2010. 92f. Tese (Doutorado em Ciência) - Faculdade de Medicina Veterinária e Zootecnia, Universidade de São Paulo, São Paulo, SP.

MARQUEZINI, G.H.L. et al. Effects of equine chorionic gonadotropin on follicle development and pregnancy rates in suckled beef cows with or without calf removal. Journal of Animal Sciences, v.91, p.12161224, 2013. Available from: <http://dx.doi.org/10.2527/jas20125382>. Acessed: Dec. 2015. doi: 10.2527/jas2012-5382.

MAUREL, M.C. et al. Réponse immunitaire à la eCG utilisée dans le traitement de l'induction d'ovulation chez la chèvre et la brebis. Gynécologie Obstétrique \& Fertilité, v.31, p.766-769, 2003. Available from: <http://dx.doi.org/10.1016/S1297-9589(03)002145>. Acessed: Dec. 2015. doi: 10.1016/S1297-9589(03)00214-5.

NOGUEIRA, E. et al. Effect of breed and corpus luteum on pregnancy rate of bovine embryo recipients. Revista Brasileira Zootecnia, v.41, n.9, p.2129-2133, 2012. Available from: <http:// dx.doi.org/10.1590/S1516-35982012000900022>. Acessed: Dec. 2015. doi: 10.1590/S1516-35982012000900022.

Ciência Rural, v.46, n.11, nov, 2016. 
PULLEY, S.L. et al. Ovarian characteristics, serum concentrations of progesterone and estradiol, and fertility in lactating dairy cows in response to equine chorionic gonadotropin. Theriogenology, v.79, p.127-134, 2013. Available from: <http://dx.doi.org/10.1016/j. theriogenology.2012.09.017>. Acessed: Dec. 2015. doi: 10.1016/j. theriogenology.2012.09.017.

RENSIS, F.; LÓPEZ-GATIUS, F. Use of Equine chorionic gonadotropin to control reproduction of the dairy cow: a review. Reproduction Domestic Animals, v.49, p.177-182, 2014. Available from: $<$ http://dx.doi.org/10.1111/rda.12268>. Acessed: Dec. 2015. doi: 10.1111/rda.12268.

RIGOGLIO, N.N. et al. Equine chorionic gonadotropin alters luteal cell morphologic features related to progesterone synthesis. Theriogenology, v.79, p.673-679, 2013. Available from: <http:// dx.doi.org/j.theriogenology.2012.11.023>. Acessed: Dec. 2015. doi: 10.1016/j.theriogenology.2012.11.023.

ROY, F. et al. The negative effect of repeated equine chorionic gonadotropin treatment on subsequent fertility in alpine goats is due to a humoral immune response involving the major histocompatibility complex. Biology of reproduction, v.60, n.4, p.805-813, 1999a. Available from: <http://dx.doi. org/10.1095/biolreprod60.4.805>. Acessed: Dec. 2015. doi: 10.1095/biolreprod60.4.805.

ROY, F. et al. Humoral immune response to equine chorionic gonadotropin in ewes: association with major histocompatibility complex and interference with subsequent fertility. Biology of reproduction, v.61, p.209-218, 1999b. Available from: <http:// dx.doi.org/10.1095/biolreprod61.1.209>. Acessed: Dec. 2015. doi: 10.1095/biolreprod61.1.209.

SANTOS, J.E. et al. Effect of human chorionic gonadotropin on luteal function and reproductive performance of highproducing lactating Holstein dairy cows. Jounal Animal Sciences, v.79, p.2881-2894, 2001. Available from: <http://dx.doi. org/2001.79112881x>. Acessed: Dec. 2015. doi: 2001.79112881x.

SILVEIRA, A.P. et al. Effect of the post-partum period on pregnancy rates of beef cows submitted to fixed time artificial insemination. Colloquium Agrariae, v.6, n.2, p.40-45, 2010. Available from: <http://dx.doi.org/10.5747/ca.2010.v06.n2.a057>. Acessed: Dec. 2015. doi: 10.5747/ca.2010.v06.n2.a057.

TORTORELLA, R.D. et al. The effect of equine chorionic gonadotropin on follicular size, luteal volume, circulating progesterone concentrations, and pregnancy rates in anestrous beef cows treated with a novel fixed-time artificial insemination protocol. Theriogenology, v.79, p.1204-1209, 2013. Available from: $\quad<$ http://dx.doi.org/101016/j.theriogenology.2013.02.019>. Acessed: Dec. 2015. doi: 101016/j.theriogenology.2013.02.019.

SÁ-FILHO, M.F. et al. Induction of ovarian follicular wave emergence and ovulation in progestin-based timed artificial insemination protocols for Bos indicus cattle. Animal Reproductin Sciences, v.129, p.132-139, 2011. Available from: <http://dx.doi. org/10.1016/j.anireprosci.2011.12.005>. Acessed: Dec. 2015. doi: 10.1016/j.anireprosci.2011.12.005. 